\title{
Pilkada DKI Jakarta 2017 : Dinamika Politik Identitas di Indonesia
}

\author{
Dina Lestari \\ Magister Ilmu Politik, Fakultas Ilmu Sosial dan Ilmu Politik Universitas Airlangga \\ e-mail: clawura@gmail.com
}

\begin{abstract}
Regional Election in one of implementation of people sovereignty that carried out directly, publicly, freely, confidentially, honestly and fairly. But regional election is often colored by identity politics in achieving pragmatic goals such as in the DKI Jakarta Election 2017. This study using a qualitative approach which is a contextual research that seeks to emphasize the meaning of a phenomenon of human behavior interactions in certain situations. This paper aims to find out about the 2017 DKI Jakarta regional election : the political identity dynamics in Indonesia. The results of this study are expected to provide input to relevant stakeholders to prevent the spread of identity politics in Indonesia.
\end{abstract}

Keywords - Regional Election, Jakarta, Identity Politics.

Abstrak - Pemilihan Gubernur, Bupati, dan Walikota (Pilkada) merupakan pelaksanaan kedaulatan rakyat yang dilaksanakan secara langsung, umum, bebas, rahasia, jujur dan adil. Namun Pilkada sering diwarnai oleh politik identitas dalam mencapai tujuan pragmatis seperti pada Pilkada DKI Jakarta 2017. Penelitian ini menggunakan pendekatan kualitatif yang merupakan penelitian yang bersifat kontekstual yang berusaha menekankan pada pemaknaan suatu fenomena interaksi tingkah laku manusia dalam situasi tertentu. Tulisan ini bertujuan untuk mengetahui dampak dari Pilkada DKI Jakarta 2017 terhadap dinamika politik indentitas di Indonesia. Hasil dari studi ini diharapkan dapat memberikan masukan terhadap stakeholder terkait untuk mencegah meluasnya politik identitas di Indonesia.

Kata Kunci: Pilkada, Jakarta, Politik Identitas

\section{PENDAHULUAN}

Pemilihan Gubernur, Bupati, dan Walikota yang selanjutnya disebut Pemilihan Kepala Daerah (Pilkada) adalah pelaksanaan kedaulatan rakyat di wilayah Provinsi dan Kabupaten/Kota untuk memilih Kepala Daerah secara langsung dan demokratis. Pilkada dilaksanakan secara demokratis berdasarkan asas langsung, umum, bebas, rahasia, jujur, dan adil sesuai dengan aturan perundangan yang berlaku.

Namun dalam pelaksanaan Pilkada, sering terjadi konflik antar kelompok yang seringkali terkait dengan isu kelompok, suku, agama, ras dan jenis kelamin dari pasangan calon Kepala Daerah. Konflik dalam Pilkada sudah sering terjadi, namun yang paling fenomenal dan menyedot perhatian masyarakat Indonesia terjadi pada Pilkada DKI tahun 2017 lalu.

Berawal ketika Basuki Cahaya Purnama atau yang biasa disebut Ahok sebagai Gubernur DKI pada waktu itu melakukan kunjungan kerja ke Pulau
Pramuka Kepulauan Seribu pada 30 September 2016. Dalam kesempatan itu, Ahok memberikan sambutan di hadapan warga dengan menyebutkan Surat Al Maidah 51 yang memancing reaksi pro kontra dari publik. Sebagian besar umat Islam marah karena merasa Surat Al Maidah telah dinistakan oleh Ahok dalam pidato tersebut.

Kasus tersebut berkembang sedemikian rupa hingga menyedot perhatian masyarakat tidak hanya di Jakarta yang sedang melaksanakan Pilkada, tetapi sebagian besar masyarakat Indonesia. Akibatnya kontestasi Pilkada DKI Jakarta Tahun 2017 diwarnai dengan isu SARA karena perbedaan yang mencolok antara calon yang satu dengan lainnya.

Politik identitas menjadi isu yang hangat dalam pemilihan gubernur DKI Jakarta 2017 karena ada keyakinan bahwa cara termudah dan paling efektif menarik hati orang untuk memilih seorang kandidat adalah dengan cara membangkitkan ikatan emosional pemilih pada calon.

Berdasarkan data dari Komisi Pemilihan Umum, 
hasil akhir pelaksanaan Pilkada DKI 2017 dimenangkan oleh Pasangan Calon Gubernur Anies Baswedan dan Sandiaga Salahuddin Uno dengan perolehan suara sebanyak 3.240 .332 atau $57,95 \%$ dari total suara sah. Hal ini menyebabkan beberapa kalangan menyimpulkan bahwa politik identitas telah berhasil digunakan sebagai alat untuk memenangkan Pemilu apabila identitas antara pasangan calon satu dan lainnya terdapat perbedaan yang cukup signifikan.

Penelitian terdahulu tentang politik identitas pada Pilkada DKI Jakarta 2017 pernah diteliti oleh Endang Sari dalam penelitian yang berjudul "Kebangkitan Politik Identitas Islam Pada Arena Pemilihan Gubernur Jakarta" pada Desember 2016. Endang Sari membahas kebangkitan politik identitas Islam pada arena pemilihan Gubernur DKI Jakarta yang dikupas dengan menggunakan perspektif konstruktivisme dari Pierre Van Den Bergh (1991) yang berpendapat bahwa politik identitas baik etnik maupun agama sengaja dikonstruksi oleh elit politik untuk mendapatkan kuasa.

Hasil penelitian menunjukkan bahwa kebangkitan politik identitas Islam terjadi melalui upaya pembangunan citra diri dan menegakkan harga diri sebagai Muslim yang terhina sehingga sesama Muslim harus memilih mereka yang seagama dan seiman. Kondisi ini dihadirkan untuk membangun psikologis sebagai mayoritas yang terluka sekaligus ruang untuk membangun batas kuasa mayoritas kepada mereka yang dipandang minoritas demi mempertahankan demarkasi kekuasaan dan kepentingan elit politik dengan mengatasnamakan agama.

Penelitian terdahulu selanjutnya mengenai politik identitas di DKI Jakarta adalah penelitian oleh Ken Miichi dengan judul "The Role of Religion and Ethnicity in Jakarta's 2012 Gubernatorial Election" pada tahun 2014. Ken Miichi melihat kemenangan Joko Widodo (Jokowi) pada Pemilihan Gubernur DKI Jakarta Tahun 2012 sebagai kemenangan demokrasi dimana Jokowi dan pasangannya Basuki Cahaya Purnama (Ahok) yang seorang Cina beragama Kristen berhasil memenangkan pemilihan meskipun ada kampanye etno-religius melawan mereka.

Dengan menganalisa hasil Pilkada DKI Jakarta
2012 yang dihubungkan dengan etnisitas dan agama hasil sensus nasional tahun 2000, hasilnya menunjukkan bahwa kampanye etno-religius dari Fauzi Bowo sebagai petahana mampu memobilisasi pemilih Betawi. Namun symbol agama lebih ditonjolkan untuk menarik pemilih muslim karena mengingat total pemilih Betawi kurang dari $30 \%$. Identitas keagamaan dapat digunakan secara pragmatis untuk melakukan eksploitasi dalam sentimen keagamaan lokal

Berdasarkan latar belakang diatas, paper ini terfokus pada Pilkada DKI Jakarta Tahun 2017 terhadap dinamika politik identitas di Indonesia. Diharapkan hasil dari kajian ini dapat memberikan pandangan dan masukan terhadap stakeholder terkait.

\section{METODE}

Jenis penelitian yang penulis gunakan adalah Fenomenologi. Pendekatan fenomenologi bertujuan memperoleh interpretasi terhadap pemahaman manusia (subyek) atas fenomena yang tampak dan makna dibalik yang tampak, yang mencul dalam kesadaran manusia.

Penelitian ini menggunakan pendekatan kualitatif yang merupakan penelitian yang bersifat kontekstual yang berusaha menekankan pada pemaknaan suatu fenomena interaksi tingkah laku manusia dalam situasi tertentu. Dengan menggunakan metode studi kepustakaan melalui buku, jurnal, artikel terkait dan menggunakan data sekunder resmi dari pihak kedua.

Metode analisis yang digunakan adalah analisis kualitatif, yaitu metode analisis yang mempergunakan pemikiran logis, analisis dengan logika, dengan induksi, analogi/ interpretasi, komparasi dan sejenisnya. Metode berfikir yang dipergunakan adalah metode induktif, yaitu dari data / fakta menuju ke tingkat abstraksi yang lebih tinggi. Dari analisis tersebut kemudian akan ditarik kesimpulan sebagai jawaban atas permasalahan yang ada.

\section{POLITIK IDENTITAS}

Dalam sosiologi, konsep identitas merupakan struktur keanggotaan individu dalam kelompok, seperti ciri, kategori dan peranan sosial. Seseorang yang memiliki identitas yang sama mempunyai persamaan kebudayaan seperti agama, bahasa, organisasi politik dan sosial dimana tumbuh 
perasaan dan kesadaran esprit de corps (kekitaan).

Definisi identitas menurut Hogg dan Abrams (1988) adalah konsep masyarakat tentang siapa dan seperti apa mereka, serta bagaimana mereka berhubungan dengan orang lain. Menurut mereka masyarakat terstruktur secara hirarkis ke dalam kategori-kategori sosial dalam penggolongan individu menurut ras, negara, kelas sosial, jenis kelamin, pekerjaan, etnis, agama dan lain sebagainya. Dimana tiap kategori tersebut terdapat suatu kekuatan, status dan martabat yang memunculkan suatu struktur sosial yang khas dalam masyarakat dan menentukan kekuatan serta status hubungan antar individu dan antar kelompok.

Konsep identitas menurut Buchari (2014) merupakan tindakan yang membedakan individu atau suatu kelompok dengan individu atau kelompok lain dan dilakukan secara terus menerus dalam interaksi sosial hingga memunculkan opini tertentu yang berkaitan dengan keberadaan individu atau kelompok tersebut. Kondisi ini akhirnya membuat kemajemukan tidak lagi sebagai ikatan dalam persatuan dan kesatuan.

Menurut Manuel Castells (2010), dalam The Power of Identity, identitas adalah sumber makna diri yang muncul dan diberikan oleh seorang individu terhadap dirinya sendiri, atau dari sekelompok orang terhadap kelompok mereka sendiri yang dibangun melalui proses individuasi. Identitas terbentuk jika ia diinternalisasi oleh masyarakat di luar dirinya. Castells membagi identitas ke dalam tiga kategori, yaitu legitimate identity, resitance identity dan project identity. Pertama, legitimate identity, identitas ini digunakan dalam proses mengenalkan institusi dominan dari suatu masyarakat untuk memperluas dan merasionalisasi dominasi mereka terhadap pelaku sosial.

Kedua, resistance identity, merupakan identitas yang dipertahankan dengan melakukan perlawanan untuk mempertahankan identitas dari stigma pihak yang melakukan dominasi. Fungsi identitas ini adalah sebagai perlawanan dan pertahanan atas perbedaan prinsip dalam institusi masyarakat. Identitas perlawanan dapat dipahami sebagai sebuah identitas yang diperjuangkan dari awal hingga akhir untuk mendapatkan pengakuan atas identitas tersebut dari pihak lain.
Ketiga, project identity, merupakan tindakan pelaku sosial yang membangun suatu identitas baru yang bertujuan mendefinisikan kembali posisi mereka dalam masyarakat dengan berusaha bertransformasi dari struktur sosial secara menyeluruh.

Lebih lanjut lagi, Identitas politik (political identity) secara konseptual berbeda dengan politik identitas (politics of identity); identitas politik merupakan konstruksi yang menentukan posisi kepentingan subjek di dalam ikatan suatu komunitas politik, sedangkan pengertian politik identitas mengacu pada mekanisme politik pengorganisasian identitas (baik identitas politik maupun identitas sosial) sebagai sumberdaya dan sarana politik.

Sementara Agnes Heller mendefinisikan politik identitas sebagai politik yang terfokus pada pembedaan sebagai kategori utamanya yang menjanjikan kebebasan, toleransi, dan kebebasan bermain (free play), walaupun memunculkan polapola intoleransi, kekerasan dan pertentangan etnis. Politik identitas dapat mencakup rasisme, biofeminisme, environmentalisme, dan perselisihan etnis.

Dari beberapa definisi diatas maka dapat ditarik kesimpulan bahwa politik identitas merupakan politik yang terfokus pada identitas sebagai unsur pembeda antara golongan satu dengan lainnya untuk mencapai tujuan. Penggunaan politik identitas tidak terlepas dari praktek politik pragmatisme yang marak digunakan untuk memenangkan suatu pemilihan umum.

\section{HASIL PENELITIAN}

\section{Pembentukan Politik Identitas}

Munculnya politik identitas dapat ditelusuri sejak berlakunya Undang-Undang Nomor 32 Tahun 2004 tentang Pemerintah Daerah, dimana kepala daerah dipillih secara langsung oleh rakyat dalam Pilkada. Dengan Pilkada maka kelompok masyarakat yang mayoritas berada dalam daerah tertentu mempunyai peluang yang lebih besar untuk memenangkan kandidat mereka. Demikian halnya dengan kebijakan desentralisasi dan otonomi daerah turut mendukung pula munculnya fenomena politik identitas.

Kemenangan etnis dayak dengan terpilihnya Cornelis sebagai gubernur Kalimantan Barat pada Pilkada 2007 menunjukkan bahwa politik identitas 
berdasarkan agama, etnis dan budaya menjadi babak baru dalam perpolitikan lokal di Indonesia.

Menurut Pengamat Politik Lembaga Ilmu Pengetahuan Indonesia (LIPI) Syamsuddin Haris, kemunculan politik identitas di Indonesia terjadi karena beberapa faktor, antara lain :

1. Dampak dari kebijakan Pemerintah yang terjadi sejak jaman Presiden Soekarno. Pemerintah tidak serius dalam membangun karakter bangsa karena hal yang dipikirkan hanya bagaimana membangun Negara (state building);

2. Sikap ambivalensi yang seringkali ditunjukkan oleh Pemerintah dalam menghadapi isu terkait negara dan agama;

3. Tidak ada peran Partai Politik dalam proses demokrasi, sehingga sentimen sectarian atau primordial menggelinding dengan sendirinya di tengah-tengah masyarakat.

Bangkitnya sentimen identitas keagamaan dalam beragam ekspresinya di Indonesia merupakan fenomena nyata terkait munculnya kesadaran dan gerakan politik baru yang menunjukkan sebuah sikap kritis terhadap keindonesiaan.

Menurut Stuart Hall, pembentukan identitas seseorang tidak dapat dilepaskan dari rasa/kesadaran terhadap ikatan kolektivitas ${ }^{\text {ee }}$. Dari pernyataan tersebut, maka ketika identitas diformulasikan sebagai sesuatu yang membuat seseorang memiliki berbagai persamaan dengan orang lain, maka pada saat yang bersamaan juga identitas memformulasikan kelompok lain. Sehingga karakteristik identitas bukan hanya dibentuk oleh ikatan kolektif, melainkan juga oleh kategori-kategori pembeda (categories of difference) .

\section{Politik Identitas dalam Pilkada DKI Jakarta 2017}

Merujuk tulisan Muhtar Haboddin (2012), berjudul "Menguatnya Politik Identitas Di Ranah Lokal" menyebutkan bahwa "menguatnya politik identitas di ranah lokal terjadi bersamaan dengan politik desentralisasi. Pasca penetapan UU No. 22/1999, gerakan politik identitas semakin jelas. Faktanya, banyak aktor baik lokal dan politik nasional menggunakan isu ini secara intens untuk pembagian kekuasaan". Dalam tulisan Muhtar Haboddin yang juga mengutip beberapa literatur ilmu politik, bahwa politik identitas dibedakan secara tajam antara identitas politik (political identity) dengan politik identitas (political of identity). Political identity merupakan konstruksi yang menentukan posisi kepentingan subjek di dalam ikatan suatu komunitas politik sedangkan political of identity mengacu pada mekanisme politik pengorganisasian identitas (baik identitas politik maupun identitas sosial) sebagai sumber dan sarana politik. Beberapa ilmuan juga membedakan antara politik identitas dengan politik etnisitas, meskipun memiliki persamaan yang cenderung menjadikan "perbedaan" sebagai instrumen politik.

Pembentukan politik identitas pada Pilkada DKI Jakarta 2017 disebabkan oleh beberapa faktor sebagai berikut :

1. Terdapat salah satu pasangan calon yang berasal dari dua minoritas, yaitu Cina (Tionghoa) dan Kristen;

2. Pidato Ahok di Pulau Pramuka Kepulauan Seribu yang menyinggung Surat Al Maidah 51 yang memicu reaksi pro kontra dalam masyarakat;

3. Media sosial berperan sangat besar dalam proses pembentukan politik identitas masyarakat Muslim di Jakarta, terutama ketika Buni Yani mengunggah video pidato Ahok di Kepulauan Seribu yang menjadi viral dan memancing kemarahan sebagian besar umat Muslim;

4. Aksi bela Islam yang dimotori oleh Gerakan Nasional Pengawal Fatwa Majelis Ulama Indonesia (GNPF-MUI), berhasil memobilisasi massa umat Islam yang merasa marah atas penghinaan Al-Quran oleh Ahok untuk menuntut agak segera diproses secara hukum.

\section{SIMPULAN}

Kemenangan Pasangan Calon Gubernur Anies Baswedan dan Sandiaga Salahuddin Uno dalam Pilkada DKI Jakarta tahun 2017 dengan perolehan suara sebanyak 3.240 .332 atau $57,95 \%$ dari total suara sah menunjukkan bahwa politik identitas berhasil digunakan sebagai alat untuk menarik simpati Pemilih kepada salah satu calon yang memiliki latar belakang identitas yang sama.

Keberhasilan ini dapat mengakibatkan elit politik yang memiliki kandidat pasangan calon dengan latar belakang identitas tertentu dari mayoritas pemilih di suatu daerah memutuskan untuk menggunakan politik identitas untuk menarik simpati Pemilih dengan identitas yang sama. Untuk 
mencegah semakin meluasnya penggunaan politik identitas yang berpotensi menimbulkan perpecahan dan mengancam persatuan, maka perlu dilaksanakan beberapa hal sebagai berikut :

1. Pemerintah harus bersikap adil dan tidak ambivalen dalam menghadapi permasalahan agama dan negara, untuk mencegah timbulnya kelompok identitas tertentu yang merasa terpinggirkan oleh kebijakan pemerintah;

2. Melakukan rekonsiliasi untuk memulihkan kondisi sosial politik yang sedang rentan perpecahan karena isu SARA dengan mengadakan pertemuan dengan para pemuka agama. Diharapkan agar para tokoh agama dapat menyampaikan himbauan dan ajakan kepada masyarakat untuk menghentikan konflik untuk menciptakan kondisi yang kondusif;

3. Komisi Pemilihan Umum sebagai penyelenggara aktif dalam melakukan kampanye anti politik identitas dengan mengundang stakeholder terkait, partai politik dan tokoh masyarakat dengan tujuan agar pihak terkait lebih paham bahaya politik identitas agar tercipta situasi kondusif di masyarakat;

4. Penegakan aturan dalam Undang-Undang No.7 Tahun 2017 pasal 280 mengenai larangan kampanye pemilu beserta ketentuan pidananya.

\section{DAFTAR PUSTAKA}

Castells, Manuel. 2010. The Power of Identity: The information age, Economi, Society, Culture. Blackwell Publishing Ltd : United Kingdom.

Greenberg, Edward F., 2017. Political Socialization, Routledge. New York.

Abdilah, Ubed S., 2001, Politik Identitas Etnis: Pergulatan Tanda Tanpa Identitas, Yayasan Indonesia, Jakarta.

Buchari Sri Astuti, 2014, Kebangkitan Etnis Menuju politik Identitas, YOI, Jakarta.

Haboddin, Muhtar, 2012, Menguatnya Politik Identitas di Ranah Lokal, Jurnal Studi Pemerintahan Universitas Brawijaya Malang, Volume 3 Nomor 1 Februari 2012.

Hogg, Michael and Dominic Abrams. 1988. Social Identifications: A Social Psychology of Intergroup Relations and Group Processes. Routledge. London.

Miichi, Ken, 2014, The Role of Religion and Ethnicity in Jakarta's 2012 Gubernatorial
Election, Journal of Current Southeast Asian Affairs 1.

Sanur L, Debora, 2017, Rekonsiliasi Politik Identitas di Indonesia, Majalah Info Singkat Vo.IX, No. 10/II/Puslit/Mei/2017.

Sari, Endang, 2016, Kebangkitan Politik Identitas Islam Pada Arena Pemilihan Gubernur Jakarta, Kritis, Volume 2 No.2 Desember 2016.

Setyaningrum, Arie, 2005, Memetakan Lokasi bagi

'Politik Identitas' dalam Wacana Politik

Poskolonial, Jurnal Mandatory Politik

Perlawanan, Edisi 2/ Tahun 2/ 2005

Undang-Undang Nomor 7 Tahun 2017 tentang Pemilihan Umum

Ayuningtyas, Rita, 2018, Mengulik Kembali Perjalanan Kasus Ahok, diakses dari https://www.liputan6.com/news/read/3322122/m engulik-kembali-perjalanan-kasus-ahok, pada tanggal 28 Oktober 2018.

Hasil Hitung TPS (Form C1) Provinsi Dki Jakarta, https://pilkada2017.kpu.go.id/hasil/2/t1/dki_jakar ta, diakses tanggal 28 Oktober 2018.

Suryowati, Estu, 2017, Faktor yang Melatarbelakangi Munculnya Sentimen Politik Primordial, diakses dari https://nasional.kompas.com/read/2017/05/04/04 530071/faktor.yang.melatarbelakangi.munculnya .sentimen.politik.primordial, pada tanggal 28 Oktober 2018. 